\title{
Pola Tutupan, Penggunaan, Serta Tantangan Kebijakan Perlindungan Ekosistem Gambut di Kabupaten Bengkalis
}

\author{
Land cover, land use, and challenges in implementing peat ecosystem protection policy \\ in Bengkalis Regency
}

Sandhi Imam Maulana ${ }^{a}$, Lailan Syaufina ${ }^{b}$, Lilik Budi Prasetyo ${ }^{c}$, Muhammad Nur Aidi $^{\mathrm{d}}$

aProgram Studi Ilmu Pengelolaan Sumberdaya Alam dan Lingkungan, Institut Pertanian Bogor, Kampus IPB Baranangsiang Bogor, 16129 , Indonesia

${ }^{b}$ Departemen Silvikultur, Fakultas Kehutanan, Institut Pertanian Bogor, Kampus IPB Dramaga Bogor, 16680, Indonesia

${ }^{\mathrm{c}}$ Departemen Konservasi Sumberdaya Hutan dan Ekowisata, Fakultas Kehutanan, Institut Pertanian Bogor, Kampus IPB Dramaga Bogor, 16680, Indonesia

${ }^{\mathrm{d} D e p a r t e m e n ~ S t a t i s t i k a, ~ F a k u l t a s ~ M a t e m a t i k a ~ d a n ~ I l m u ~ P e n g e t a h u a n ~ A l a m, ~ I n s t i t u t ~ P e r t a n i a n ~ B o g o r, ~ K a m p u s ~ I P B ~ D r a m a g a ~ B o g o r, ~}$ 16680, Indonesia

\section{Article Info:}

Received: 16 - 08 - 2018

Accepted: 29 - 04 - 2019

Keywords:

Peat, cover, use, protection, Bengkalis.

Corresponding Author:

Lailan Syaufina

Departemen Silvikultur, Fakultas

Kehutanan, Institut Pertanian

Bogor;

Tel. +62 2518626806

Email: lailans@apps.ipb.ac.id

\begin{abstract}
Since the issuance of Government Rule No. 71/2014 jo. No. 57/2016, there has been a wide debate, because those rules may trigger other problems such as food security, social, economic, political, as well as peatland cultivation security. Considering this issue, this study aims to analyze challenges in implementing peat protection policies as textually arranged in Government Rule No. 71/2014 jo. No. 57/2016, in Bengkalis Regency. Overall, in order to discuss both of rule in form and rule in use aspects, this study was conducted using maps overlay technique and content analysis on Government Rule No. 71/2014 jo. No. 57/2016. Based on those approaches, this study shows that there are four challanges in implementing previously mentioned peat ecosystem protectetion policies in Bengkalis Regency, particularly in regard to the measurement of damaged peatland criteria, frictions between protection incentives and pressure on peatland conversion, significant economic contraction, up to the emergence of new open access areas that often be illegally occupied and worsening peatland existing conditions. This finding implies that the government as the regulator in the implementation of peat ecosystem protection policies should open a wider room for policy improvements, in order provide a more balanced consideration to three important aspects of sustainable development, which is not only limited to environmental sustainability, but also covering both of social and economic sustainability.
\end{abstract}

\footnotetext{
How to cite (CSE Style $8^{\text {th }}$ Edition):

Maulana SI, Syaufina L, Prasetyo LB, Aidi MN. 2019. Pola Tutupan, Penggunaan, Serta Tantangan Kebijakan Perlindungan Ekosistem Gambut di Kabupaten Bengkalis. JPSL 9(3): 549-565. http://dx.doi.org/10.29244/jps1.9.3.549-565.
}

\section{PENDAHULUAN}

Dalam bukunya yang berjudul "Ecology and Management of Tropical Peat Soils", Andriesse (1988) menyebutkan bahwa secara tradisional, gambut dapat didefinisikan sebagai tanah yang terbentuk pada lahanlahan basah yang tersusun dari jaringan berbagai tumbuhan dan lumut-lumutan yang terdekomposisi sebagian sehingga memiliki kandungan bahan organik yang tinggi. Definisi tersebut juga tercermin dalam Peraturan 
Pemerintah No. 71 Tahun 2014, yang menyebut gambut sebagai material organik yang terbentuk secara alami dari sisa-sisa tumbuhan yang terdekomposisi tidak sempurna dan terakumulasi pada rawa. Sementara itu, berdasarkan data sebaran lahan gambut yang dipublikasikan dalam Wahyunto et al. (2014), secara keseluruhan setidaknya terdapat 14.9 juta hektar lahan gambut di Indonesia, dimana sebaran terluasnya didominasi oleh tiga pulau besar, yaitu Sumatera, Kalimantan, dan Papua. Dari sudut pandang geografis, Wahyunto et al. (2014) juga menyebutkan bahwa di Pulau Sumatera, lahan gambut terluas terbentuk di sepanjang daerah pesisir timur, termasuk di wilayah administrasi Kabupaten Bengkalis, Provinsi Riau.

Secara alami, gambut memiliki fungsi yang signifikan sebagai penyimpan air, perlindungan habitat keragaman hayati, serta fungsi ekonomi (Agus et al. 2016). Namun demikian, berbagai kegiatan eksploitasi lahan gambut demi pencapaian kemakmuran manusia tanpa memperhatikan aspek konservasi dapat menimbulkan ancaman rusaknya fungsi lindung, keragaman hayati, serta kemampuan gambut dalam menjaga cadangan karbon dalam jumlah yang signifikan. Selain itu, bersamaan dengan hilangnya fungsi gambut dalam menyimpan air, maka daerah di sekitar area kubah gambut akan sangat rentan terhadap paparan bencana kekeringan maupun kebanjiran.

Dalam rangka mencegah kerusakan lebih lanjut terhadap ekosistem gambut, pemerintah sendiri telah memiliki rangkaian kebijakan sebagai dasar hukum upaya perlindungan ekosistem gambut, termasuk diantaranya yang terbaru adalah PP No. 71/2014 tentang Perlindungan dan Pengelolaan Ekosistem Gambut dan PP No. 57/2016 tentang Perubahan Atas PP No. 71/2014. Namun demikian, sejak awal ditetapkan hingga saat ini, kedua peraturan tersebut terus menuai banyak perdebatan. Terutama dari para praktisi, peneliti dan akademisi, yang menilai bahwa implementasi kebijakan perlindungan ekosistem gambut dalam peraturan tersebut dapat menimbulkan berbagai masalah, terutama terkait ketahanan pangan, sosial, ekonomi, politik, hingga keamanan kawasan budidaya pada lahan gambut (Wardani 2016; Amri 2017). Mempertimbangkan permasalahan tersebut, terutama pada lingkup wilayah administrasi Kabupaten Bengkalis, studi ini bertujuan untuk menganalisis tantangan yang timbul dalam implementasi kebijakan perlindungan ekosistem gambut berdasarkan gambaran kondisi pola tutupan dan penggunaan yang ada di Kabupaten Bengkalis.

\section{METODE}

\section{Lokasi Penelitian}

Penelitian ini dilaksanakan pada lingkup wilayah administrasi Kabupaten Bengkalis, Riau, seperti yang diilustrasikan pada Gambar 1. Secara astronomis, kabupaten ini terletak antara 207'37.2"-055'33.6" Lintang Utara dan 100'57'57.6"-102'30'25.2" Bujur Timur. Wilayah Kabupaten Bengkalis terdiri atas sebelas kecamatan yaitu Kecamatan Bandar Laksamana, Kecamatan Bathin Solapan, Kecamatan Talang Muandau, Kecamatan Mandau, Kecamatan Pinggir, Kecamatan Bukit Batu, dan Kecamatan Siak Kecil yang terletak di pesisir timur daratan Pulau Sumatera. Kecamatan Rupat dan Kecamatan Rupat Utara yang terletak di Pulau Rupat. Sedangkan Kecamatan Bengkalis dan Kecamatan Bantan di Pulau Bengkalis. Menurut data BPS (2017), secara keseluruhan, luas daratan di wilayah kabupaten ini mencapai $7773.93 \mathrm{~km}^{2}$, yang didominasi oleh dataran rendah dengan ketinggian rata-rata 2-6 mdpl.

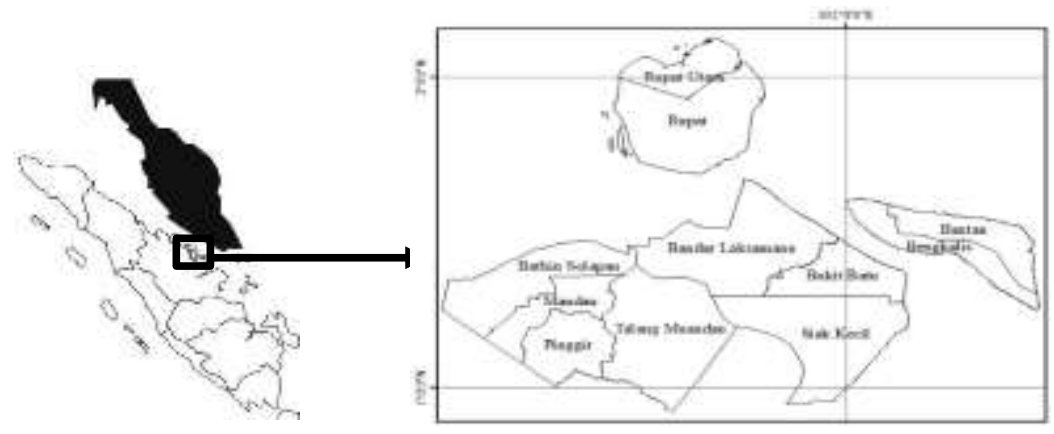

Gambar 1 Lokasi penelitian 


\section{Jenis dan Sumber Data}

Data yang dikumpulkan dalam penelitian ini adalah berbagai peta yang meliputi:

- Peta batas administrasi kabupaten dan kecamatan dari Badan Pusat Statistik (BPS).

- Peta Fungsi Ekosistem Gambut Nasional yang telah ditetapkan berdasarkan SK Menteri LHK No. 130 Tahun 2017 dari Direktorat Jenderal Planologi Kehutanan dan Tata Lingkungan, Kementerian Lingkungan Hidup dan Kehutanan.

- Peta sebaran lahan gambut dari Kementerian Pertanian.

- Peta kedalaman dan tipe dekomposisi gambut yang diekstrak dari Peta Sebaran Lahan Gambut dari Wetlands International Indonesia (WII).

- Peta klasifikasi tutupan dan penggunaan lahan yang telah disusun berdasarkan Standar Nasional Indonesia (SNI) 7645 oleh BIG, yang mencakup area pertanian (perkebunan, ladang, sawah); area non-pertanian yang mencakup hutan lahan basah (hutan bakau/mangrove), hutan lahan kering (hutan rimba), permukiman dan tempat kegiatan, semak belukar, alang-alang; serta badan air (danau/situ, empang, tambak).

- Peta jaringan drainase buatan/kanal yang diekstrak dari Peta Rupa Bumi Indonesia (RBI) dari BIG.

- Peta jaringan jalan yang diekstrak dari Peta Rupa Bumi Indonesia (RBI) dari BIG, yang mencakup jalan arteri, jalan lokal, jalan lingkungan dan jalan lain.

Peta konsesi perkebunan kelapa sawit dan hutan tanaman (IUPHHK-HT) yang mencakup informasi penanggung jawab usaha, status ijin usaha, dan luas area pengusahaan yang diperoleh dari Global Forest Watch-World Resources Institute.

\section{Analisis Data}

Tahapan pertama dalam studi ini adalah melaksanakan teknik tumpang susun terhadap data/peta yang telah dikumpulkan, dalam rangka mendapatkan gambaran kondisi tutupan dan penggunaan lahan gambut yang terlihat di Kabupaten Bengkalis, sebagaimana telah disarankan dalam Suwarno et al. (2016). Adapun peralatan yang digunakan dalam tahap ini adalah perangkat keras dan lunak standar untuk pemrosesan data berbasis Geographic Information System (GIS).

Selanjutnya, untuk menganalisis beragam tantangan yang timbul dalam implementasi kebijakan perlindungan gambut, dilaksanakan analisis kandungan isi (content analysis) terhadap PP No. 71/2014 jo. PP No. 57/2016, seperti yang disarankan oleh Mayring (2014). Kombinasi pendekatan berbasis analisis spasial dan analisis kebijakan semacam ini dapat membantu dalam mengulas permasalahan implementasi suatu kebijakan publik dengan membandingkan aspek kandungan tekstual suatu naskah peraturan (rule in form) dengan aspek kondisi yang ada di lapangan (rule in use) (Worrall dan Bond 1997; Djaelani 2011; Purbawiyatna et al. 2012; Zook et al. 2018).

\section{HASIL DAN PEMBAHASAN}

\section{Batas administrasi dan batas Kesatuan Hidrologis Gambut}

Secara administratif, sebelum tahun 2017, hanya terdapat 8 kecamatan di Kabupaten Bengkalis. Namun, dengan diresmikannya tiga kecamatan baru pada tanggal 9 Februari 2017 yang sebelumnya juga telah ditetapkan berdasarkan Perda Kab. Bengkalis No. 6 Tahun 2015, maka jumlah kecamatan berubah menjadi 11. Tiga kecamatan baru tersebut antara lain Kecamatan Bathin Solapan yang dimekarkan dari wilayah Kecamatan Mandau, Kecamatan Bandar Laksamana yang dimekarkan dari wilayah Kecamatan Bukit Batu, serta Kecamatan Talang Muandau yang dimekarkan dari wilayah Kecamatan Pinggir.

Merujuk pada PP No. 71 Tahun 2014 jo. PP No. 57 Tahun 2016, Kesatuan Hidrologis Gambut (KHG) didefinisikan sebagai "ekosistem gambut yang letaknya di antara 2 (dua) sungai, di antara sungai dan laut, dan/atau pada rawa", dimana ekosistem gambut merupakan "tatanan unsur gambut yang merupakan satu 
kesatuan utuh menyeluruh yang saling mempengaruhi dalam membentuk keseimbangan, stabilitas, dan produktivitasnya". Sebagaimana terlihat pada Gambar 2, pada wilayah administrasi Kabupaten Bengkalis terdapat 6 KHG, yang meliputi dua KHG Kabupaten/kota dan empat KHG Lintas Kabupaten/Kota. Tumpang susun antara Peta batas administrasi kabupaten dan Peta KHG yang telah ditetapkan berdasarkan SK Menteri LHK No. 130 Tahun 2017, juga memperlihatkan terdapat 5 kecamatan yang 100\% wilayahnya termasuk dalam cakupan KHG, yaitu Kecamatan Bantan, Bengkalis, Siak Kecil, Bukit Batu, dan Bandar Laksamana.

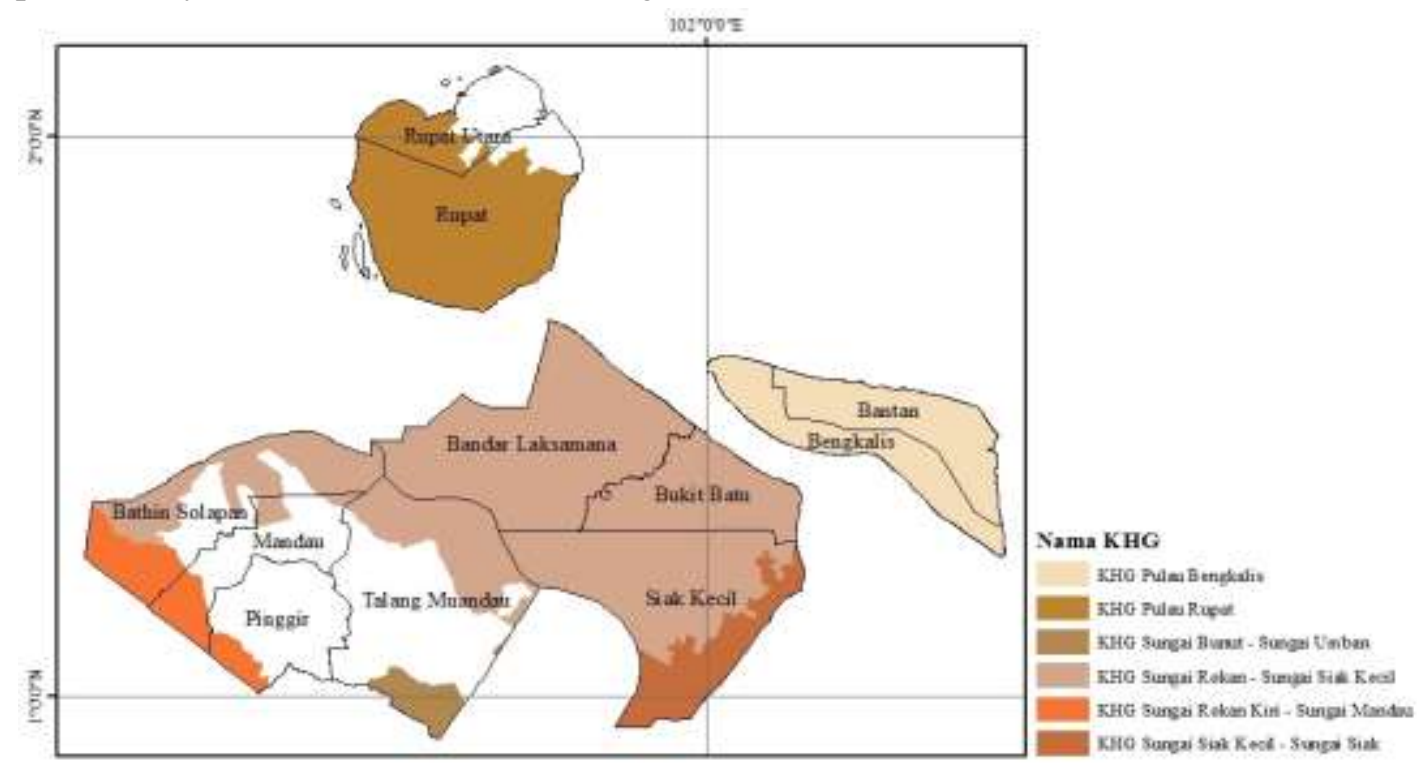

Gambar 2 Kesatuan Hidrologis Gambut (KHG) di Kabupaten Bengkalis

Selain itu, merujuk pada Tabel 1, terlihat bahwa setidaknya terdapat tiga kecamatan yang wilayahnya didominasi oleh fungsi lindung ekosistem gambut sesuai dengan ketentuan pada PP No. 71 Tahun 2014 jo. PP No. 57 Tahun 2016, seperti pada Kecamatan Siak kecil, Bukit Batu, dan Bandar Laksamana yang baru saja dimekarkan. Kondisi semacam ini memerlukan perhatian khusus, karena seiring dengan meningkatnya tekanan pembangunan dan pengembangan daerah maka tekanan konversi kawasan gambut untuk memenuhi kebutuhan permukiman, tempat kegiatan, dan pangan juga akan semakin tinggi, sebagaimana juga diungkapkan dalam studi oleh Pranoto et al. (2017). Sementara itu, melihat status KHG pada Kabupaten Bengkalis yang mayoritas termasuk dalam KHG lintas Kabupaten/Kota, maka pemerintah kabupaten perlu mengantisipasi lemahnya integrasi antara kebijakan pada masing-masing tingkat pemerintahan dengan tingkat pemerintah yang lainnya hingga tingkat tapak, terutama terkait dengan penguasaan dan pengelolaan lahan.

Tabel 1 Cakupan KHG pada wilayah administrasi Kabupaten Bengkalis

\begin{tabular}{|c|c|c|c|c|c|c|}
\hline \multirow[b]{2}{*}{ No. } & \multirow[b]{2}{*}{ Nama KHG } & \multirow[b]{2}{*}{ Status KHG } & \multirow[b]{2}{*}{$\begin{array}{c}\text { Wilayah } \\
\text { Administrasi } \\
\text { Kecamatan }\end{array}$} & \multicolumn{2}{|c|}{ Luas Area } & \multirow[b]{2}{*}{$\begin{array}{l}\text { Total } \\
\text { (Ha) }\end{array}$} \\
\hline & & & & $\begin{array}{l}\text { Fungsi } \\
\text { Lindung } \\
(\mathrm{Ha})\end{array}$ & $\begin{array}{c}\text { Fungsi } \\
\text { Budidaya } \\
(\mathrm{Ha})\end{array}$ & \\
\hline \multirow[t]{2}{*}{1.} & KHG Pulau Rupat & Kabupaten/Kota & Rupat Utara & 789.8 & 18292.2 & 19082.0 \\
\hline & & & Rupat & 49248.4 & 49928.7 & 99177.2 \\
\hline \multirow[t]{2}{*}{2.} & KHG Pulau & Kabupaten/Kota & Bantan & 19332.6 & 27711.7 & 47044.4 \\
\hline & Bengkalis & & Bengkalis & 21002.0 & 22491.6 & 43493.6 \\
\hline 3. & $\begin{array}{l}\text { KHG Sungai Bunut- } \\
\text { Sungai Umban }\end{array}$ & $\begin{array}{l}\text { Lintas } \\
\text { Kabupaten/Kota }\end{array}$ & Talang Muandau & 5566.0 & 6712.2 & 12278.2 \\
\hline \multirow[t]{2}{*}{4.} & & Lintas & Bathin Solapan & 11920.6 & 32271.2 & 44191.8 \\
\hline & & Kabupaten/Kota & Mandau & 282.3 & 4178.5 & 4460.8 \\
\hline
\end{tabular}




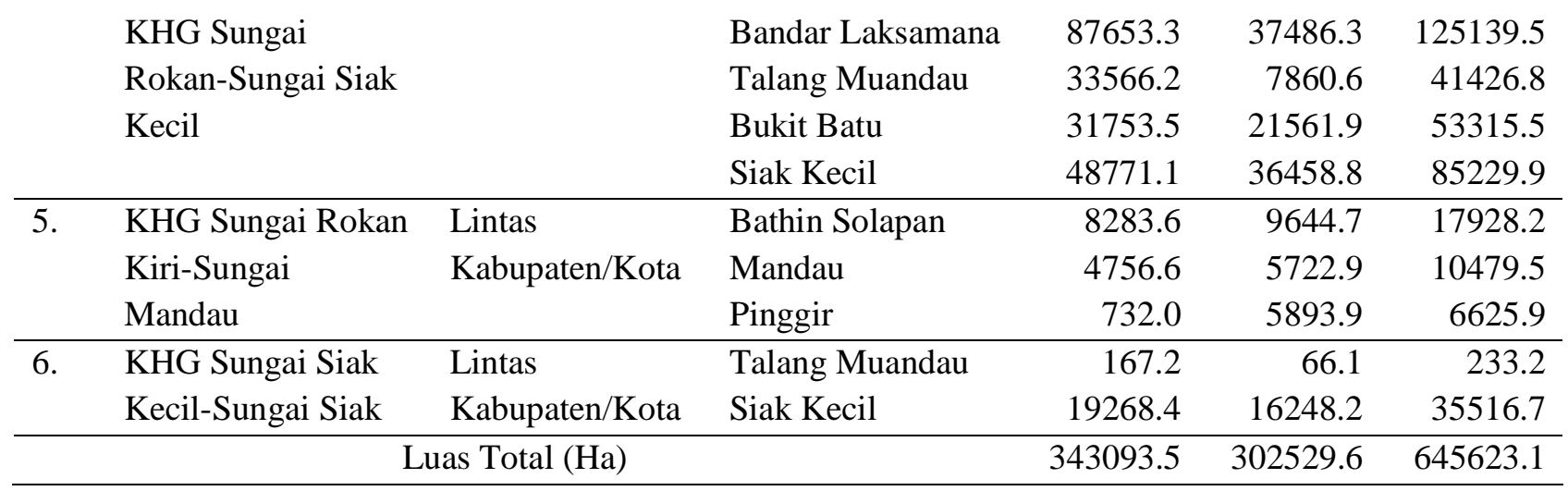

\section{Sebaran Kedalaman dan Tipe Dekomposisi Gambut}

Menurut versi terbaru dari Soil Taxonomy (Soil Survey Staff 2014), gambut diklasifikasikan dalam kelompok Histosol. Hingga saat ini memetakan sebaran kedalaman serta tipe dekomposisi gambut, diperlukan kegiatan penelitian dan survey yang intensif dengan biaya yang tinggi, sehingga informasi luas sebaran kedalaman serta tipe dekomposisi gambut masih berupa perkiraan (Agus et al. 2016).

Pada tahun 2002 hingga 2005 Wetlands International Indonesia (WII) telah menyusun peta lahan gambut untuk Pulau Sumatera, Kalimantan, dan Papua yang memuat informasi sebaran kedalaman dan tipe dekomposisi gambut berdasarkan hasil analisis citra satelit dan kompilasi peta/data tanah yang telah ada (Wahyunto et al. 2004; 2005). Kemudian, Balai Besar Sumberdaya Lahan Pertanian-Kementerian Pertanian (BBSDLP) melakukan pembaharuan peta lahan gambut tersebut menggunakan data warisan tanah dan hasil survey pemetaan tanah yang dilakukan hingga tahun 2011 (Ritung et al. 2011). Namun demikian, secara keseluruhan, peta lahan gambut BBSDLP tersebut tidak dilengkapi dengan informasi sebaran tipe dekomposisi gambut. Hal ini dikarenakan survey sebaran tipe dekomposisi gambut hanya dilaksanakan pada lima daerah pewakil, yakni Pelalawan-Riau, Muaro-Jambi, Kubu Raya-Kalimantan Barat, Pulang Pisau-Kalimantan Tengah, dan Kuala Kencana-Mimika (Agus et al. 2016).

Dalam rangka mendapatkan informasi terkini dari sebaran kedalaman dan tipe dekomposisi gambut di Kabupaten Bengkalis pada studi ini maka dilaksanakan tumpang susun antara peta kedalaman dan tipe dekomposisi gambut dari WII sebagaimana dipublikasikan dalam Wahyunto et al. (2005), peta sebaran lahan gambut dari Kementerian Pertanian seperti yang dipublikasikan oleh Ritung et al. (2011), serta peta Fungsi Ekosistem Gambut Nasional yang telah ditetapkan berdasarkan SK Menteri LHK No. 130 Tahun 2017. Secara umum, sebagaimana terlihat pada Gambar 3, hasil analisis tumpang susun tersebut menunjukkan bahwa luas lahan gambut di Kabupaten Bengkalis setidaknya mencapai $522799.2 \mathrm{Ha}$ atau 67.25\% dari total wilayah administrasinya. Sementara itu, ditinjau dari segi tipe dekomposisinya, sebagaimana dirinci pada Tabel 2, lahan gambut di Kabupaten Bengkalis didominasi oleh gambut tipe hemik dan saprik dengan kelas kedalaman yang variatif.

Menurut Agus et al. (2016) tipe gambut hemik dan saprik pada kelas kedalaman kurang dari $200 \mathrm{~cm}$, seperti yang banyak ditemukan di Kabupaten Bengkalis, termasuk dalam kategori sesuai untuk kegiatan budidaya tanaman tahunan. Lebih detail, Wahyunto et al. (2013) menyebutkan bahwa dengan tingkat pengelolaan yang rendah hingga sedang, gambut pada kelas kedalaman 100-200 cm relatif sesuai untuk kegiatan budidaya tanaman hortikultura buah-buahan, seperti nanas, pisang, rambutan, nangka; serta tanaman perkebunan, seperti karet, kelapa, kelapa sawit, kopi, dan sagu. Melihat kondisi tersebut, apabila dihadapkan dengan ketentuan perlindungan ekosistem gambut sebagaimana diatur dalam PP No. 71 Tahun 2014 jo. PP No. 57 Tahun 2016, maka permasalahan pemanfaatan dan pengembangan lahan gambut di masa datang akan semakin dilematis bagi Kabupaten Bengkalis. Hal ini dikarenakan, dengan terbatasnya lahan mineral yang potensial, salah satu pilihan sumberdaya lahan yang masih dapat diharapkan adalah lahan gambut, baik yang termasuk dalam kategori fungsi budidaya maupun lindung. Permasalahan ini semakin pelik 
terutama pada daerah-daerah kecamatan yang baru terbentuk, yang pada dasarnya masih memerlukan sumberdaya lahan untuk mendukung pembangunan dan pertumbuhan ekonominya, namun wilayahnya didominasi oleh lahan gambut yang telah ditetapkan sebagai fungsi lindung, seperti pada Kecamatan Bandar Laksamana. Dilema semacam ini memerlukan adanya kebijakan dan strategi yang dapat memayungi baik aspek ekonomi, sosial, dan lingkungan secara seimbang dan saling menguntungkan.

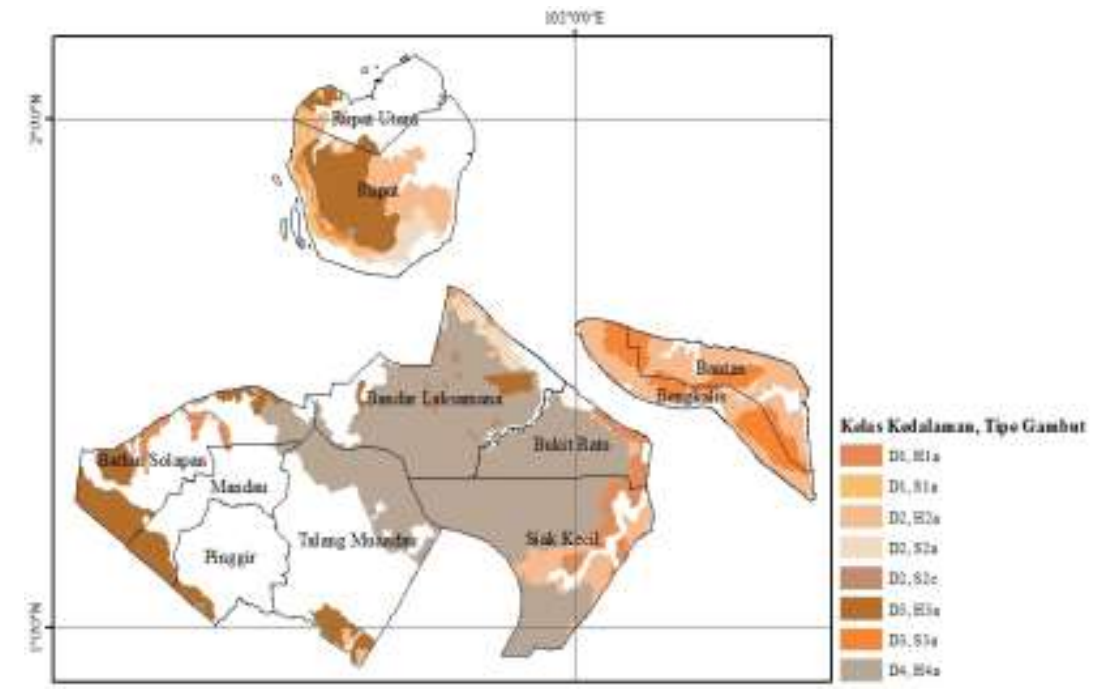

Gambar 3 Sebaran kedalaman dan tipe gambut di Kabupaten Bengkalis

Kendala lain dalam implementasi PP No. 71 Tahun 2014 jo. PP No. 57 Tahun 2016 adalah pada Pasal 23 ayat 3 yang mengatur kriteria kerusakan gambut. Pada pasal tersebut, secara tekstual jelas disebutkan bahwa ekosistem gambut dengan fungsi budidaya dinyatakan rusak apabila memenuhi kriteria baku kerusakan muka air tanah lebih dari 0.4 (nol koma empat) meter di bawah permukaan gambut pada titik penaatan; dan/atau terungkapnya sedimen berpirit dan/atau kwarsa di bawah lapisan Gambut. Namun demikian merujuk pada tingginya keberagaman kedalaman dan tipe dekomposisi gambut di Kabupaten Bengkalis (Tabel 1), serta lingkungan pembentukan gambut di kabupaten ini yang termasuk dalam kategori gambut topogen (Subiksa dan Wahyunto 2013; Agus et al. 2016), maka terdapat kecenderungan bahwa tinggi muka air tanah gambut akan selalu berfluktuasi mengikuti kondisi curah hujan (Winarna, 2015; Indonesian Oil Palm Research Insttitute [IOPRI] 2017; Gambar 4). Hal ini dimungkinkan terjadi karena sebagai suatu kesatuan hidrologis dengan dua sungai yang mengapitnya, maka dinamika tinggi air gambut akan sangat terpengaruh pada dinamika air sungai. Pada musim kemarau berkepanjangan dimana debit air sungai umumnya turun drastis, maka tinggi air gambut juga terpengaruh sehingga dapat saja tinggi muka air tanah gambut lebih dari 0.4 meter dan masuk dalam kategori rusak. Hal ini secara alami berpotensi menyebabkan kerusakan terlepas dari kesalahan pengelola gambut tetapi karena turunnya debit air sungai secara alami.

Selain itu, bertentangan dengan penggunaan kriteria TMA 0.4 meter untuk mengklasifikasikan gambut dalam kategori rusak, hasil studi oleh Winarna (2015) juga menunjukkan bahwa dengan pengelolaan kedalaman muka air tanah kurang dari atau sama dengan $70 \mathrm{~cm}$ di bawah permukaan tanah terbukti masih menunjukkan adanya penurunan emisi $\mathrm{CO}_{2}$ tanah gambut dengan tutupan tanaman kelapa sawit berumur 6 tahun. Selain itu, pengelolaan kedalaman muka air tanah kurang dari atau sama dengan $70 \mathrm{~cm}$ di bawah permukaan tanah masih dapat meningkatkan produksi kelapa sawit umur 6 tahun pada tahun pertama penelitian hingga 8-11\%. Hasil penelitian Winarna (2015) tersebut mengindikasikan bahwa pada rentang TMA 0.4-0.7 meter, lahan gambut masih belum dapat dikategorikan sebagai gambut yang rusak. Oleh karena itu, penetapan kriteria tinggi muka air gambut semestinya dapat direvisi agar bersifat dinamis pada suatu kisaran (misal 0.4 $0.8 \mathrm{~m})$ daripada statis pada satu besaran angka saja $(0.4 \mathrm{~m})$. 
Tabel 2 Sebaran kedalaman dan tipe dekomposisi/kematangan gambut di Kabupaten Bengkalis

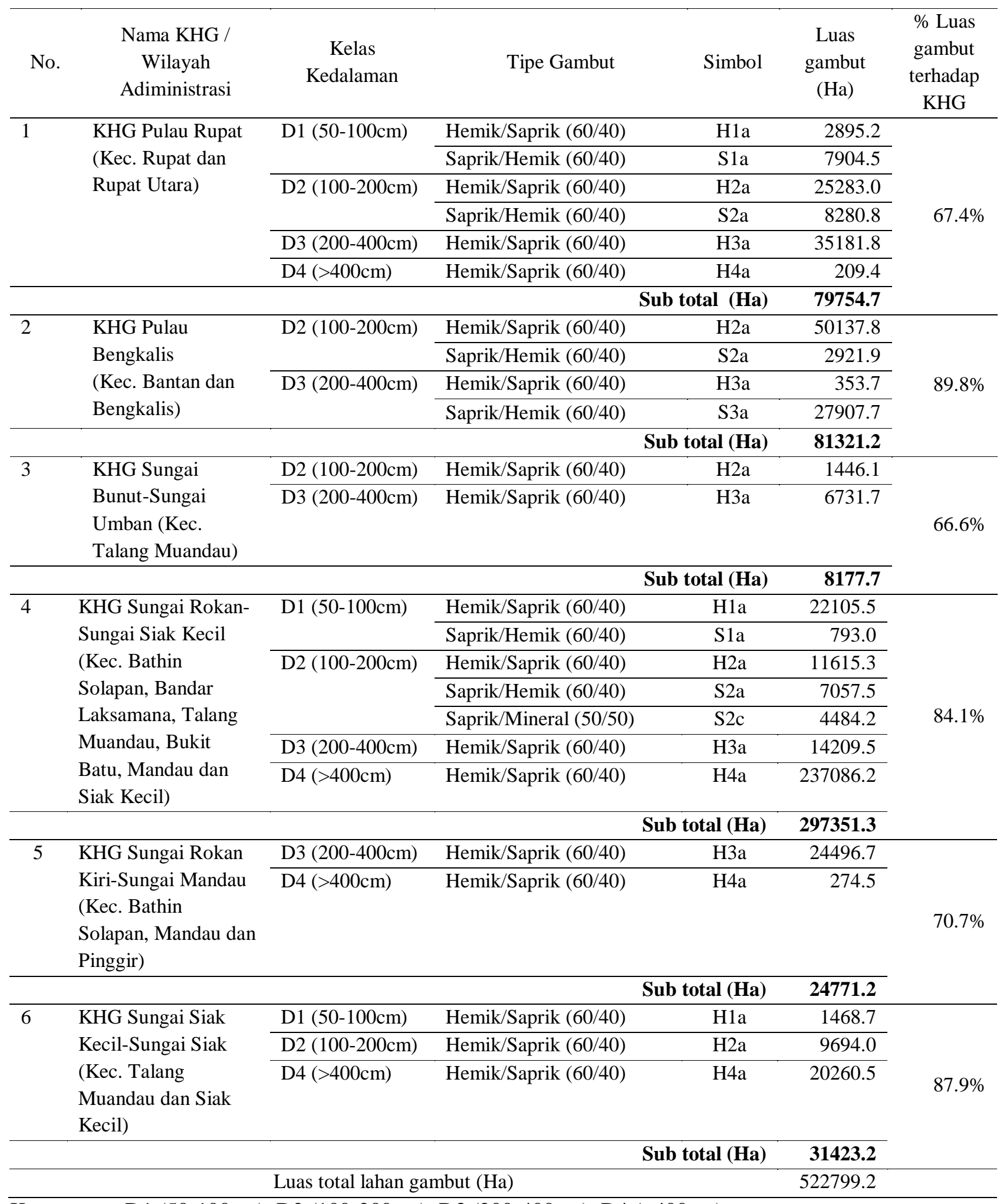

Keterangan: D1 (50-100cm), D2 (100-200cm), D3 (200-400cm), D4 (>400cm) 


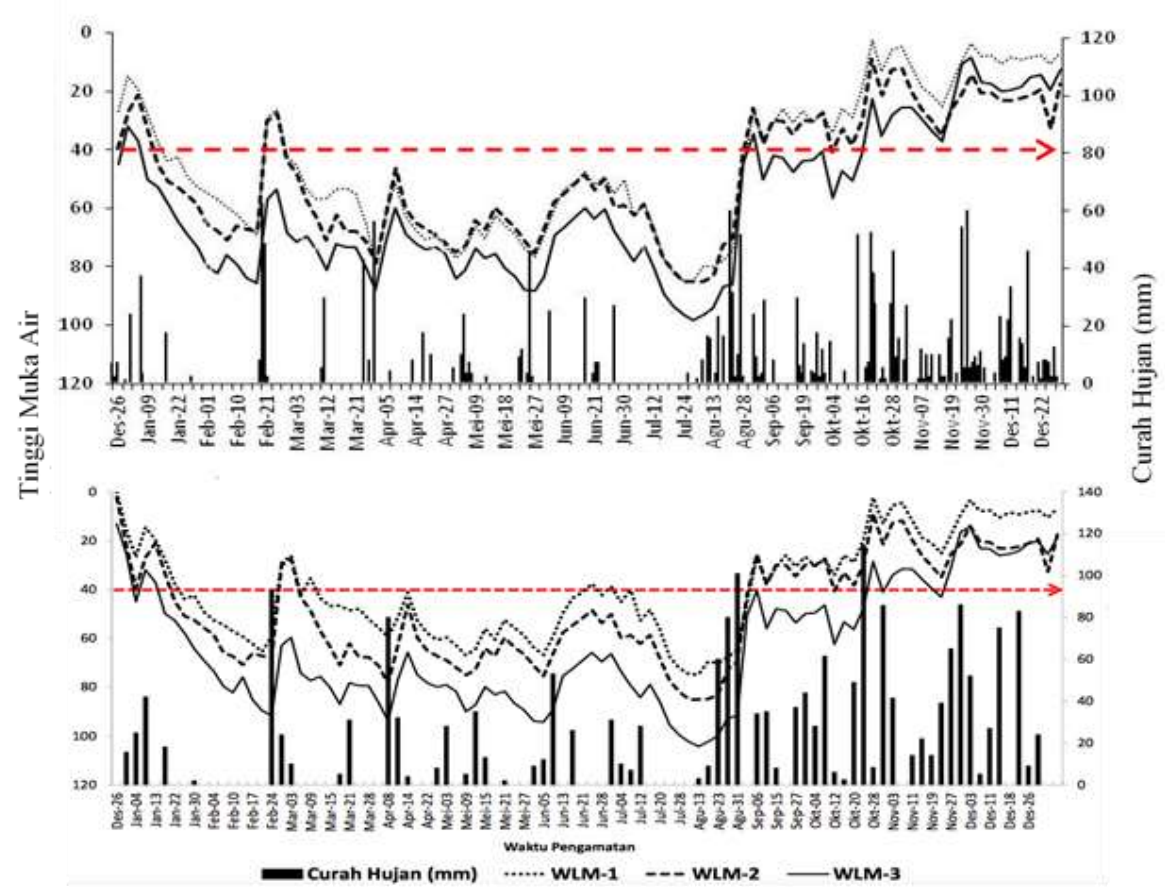

Gambar 4 Fluktuasi tinggi muka air (TMA) gambut menurut curah hujan Sumber: Winarna (2015), IOPRI (2017)

\section{Pola tutupan dan penggunaan}

\section{Klasifikasi tutupan dan penggunaan}

Informasi mengenai kondisi eksisting tutupan dan penggunaan lahan gambut pada studi ini didapatkan melalui pendekatan tumpang susun antara peta lahan gambut dari Wetlands International Indonesia (WII) sebagaimana dipublikasikan dalam Wahyunto et al. (2005), peta sebaran lahan gambut dari Kementerian Pertanian hasil updating tahun 2011 seperti yang dipublikasikan oleh Ritung et al. (2011), peta Fungsi Ekosistem Gambut Nasional yang telah ditetapkan berdasarkan SK Menteri LHK No. 130 Tahun 2017, dengan peta klasifikasi tutupan dan penggunaan lahan tahun 2016 dari Badan Informasi Geospasial (BIG). Pendekatan serupa juga telah diterapkan oleh Agus et al. (2016), yang menimpang-susunkan peta lahan gambut dari Ritung et al. (2011) dengan peta penutupan lahan tahun 2012 dari Kementerian Kehutanan, dalam rangka untuk mengetahui kondisi lahan gambut di Sumatera, Kalimantan, dan Papua.

Secara keseluruhan, seperti yang tersaji pada Gambar 5 dan Tabel 3, terdapat 11 tipe tutupan dan penggunaan yang dapat diidentifikasi pada lahan gambut di Kabupaten Bengkalis. Adapun tipe tutupan dan penggunaan yang mendominasi antara lain perkebunan (42.2\%), hutan (44.9\%), dan semak belukar (11.2\%). Sementara itu, proporsi untuk permukiman dan tempat kegiatan, serta tegalan/ladang setidaknya mencapai $0.7 \%$ dan $0.6 \%$ dari total lahan gambut di kabupaten ini. Sedangkan, enam kategori tutupan dan penggunaan lainnya, seperti hutan bakau/mangrove, sawah, tanah kosong/gundul, danau, empang, dan tambak hanya berkisar antara 0.01-0.19\%. Besarnya proporsi penggunaan lahan gambut untuk perkebunan di kabupaten ini sejalan dengan studi yang sebelumnya telah dilaksanakan oleh Miettinen et al. (2016) dan Agus et al. (2016). 


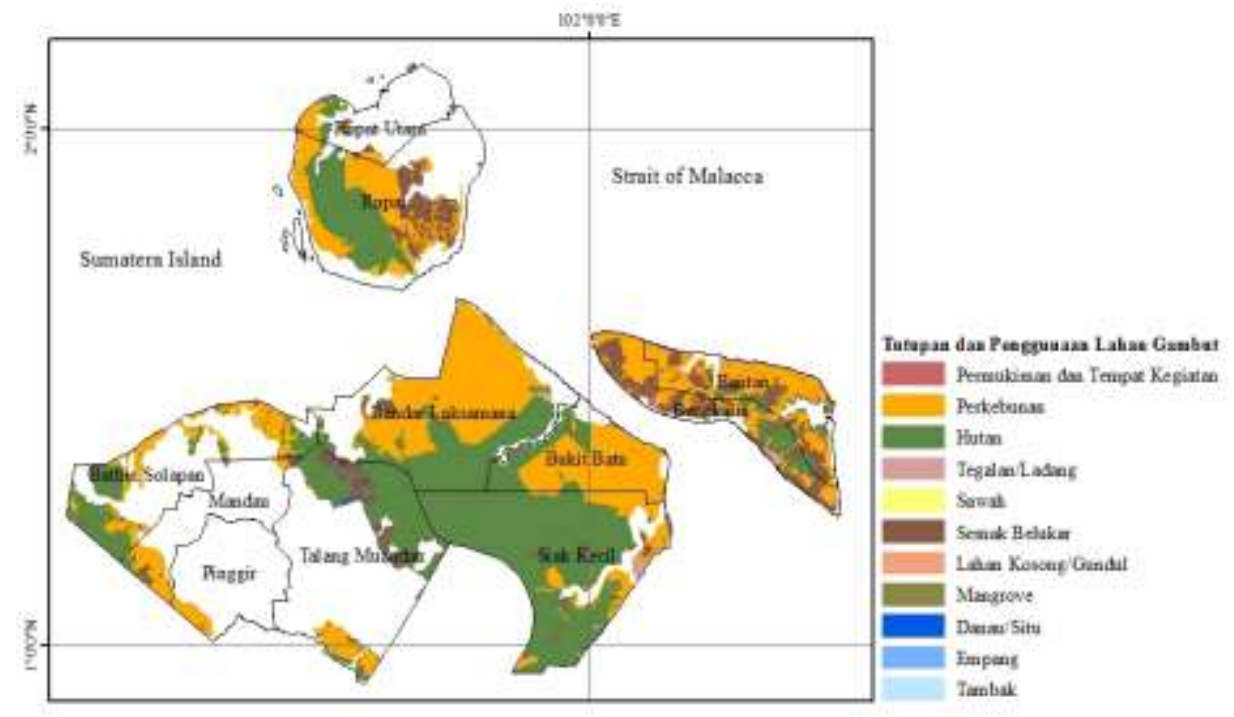

Gambar 5 Tutupan dan penggunaan lahan gambut di Kabupaten Bengkalis

Besarnya proposi luasan perkebunan tersebut mengindikasikan bahwa sektor ini memiliki peran yang signifikan dalam pembangunan dan perekonomian di Kabupaten Bengkalis. Secara umum, besarnya kontribusi sektor perkebunan tersebut tidaklah mengherankan karena pada dasarnya perekonomian daerah memang sangat dipengaruhi oleh potensi yang dimilikinya. Sebagaimana dilaporkan oleh Syahza (2011) bahwa potensi utama yang sesuai untuk dikembangkan di kabupaten ini adalah pengembangan perkebunan karena dari segi karakteristik fisiografis daerahnya yang datar dapat menekan biaya produksi. Selain itu, dari segi pemasaran hasil produksinya (e.g. CPO, pulp dan kertas), kabupaten ini juga diuntungkan karena letaknya yang strategis dengan pasar internasional. Oleh karena itu, arah kebijakan pembangunan didaerah ini sangat sulit untuk dipisahkan dari pengembangan sektor perkebunan, termasuk diantaranya perluasan area budidaya, baik dengan menerapkan sistem inti rakyat maupun dengan membuka kesempatan pada sektor swasta. Mempertimbangkan hal tersebut, pemerintah semestinya dapat segera merumuskan dan memperjelas program penggantian lahan usaha untuk menggantikan areal perkebunan dan hutan tanaman yang menurut PP No. 71 Tahun 2014 jo. PP No. 57 Tahun 2016 perlu direstorasi. Hal ini perlu segera dilaksanakan dalam rangka mengurangi potensi friksi antara pemerintah pusat dan daerah.

Tabel 3 Pola tutupan dan penggunaan lahan gambut di Kabupaten Bengkalis

\begin{tabular}{|c|c|c|c|c|c|c|c|c|c|c|c|c|c|}
\hline \multirow[b]{2}{*}{ No. } & \multirow{2}{*}{$\begin{array}{l}\text { Klasifikasi tutupan } \\
\text { dan penggunaan }\end{array}$} & \multicolumn{12}{|c|}{ Kecamatan } \\
\hline & & $\begin{array}{l}\text { Rupat } \\
\text { Utara }\end{array}$ & Rupat & Bantan & $\begin{array}{l}\text { Bengkal } \\
\text { is }\end{array}$ & $\begin{array}{c}\text { Bandar } \\
\text { Laksamana }\end{array}$ & Bukit Batu & $\begin{array}{c}\text { Bathin } \\
\text { Solapan }\end{array}$ & Mandau & Pinggir & $\begin{array}{c}\text { Siak } \\
\text { Kecil }\end{array}$ & $\begin{array}{c}\text { Talang } \\
\text { Muandau }\end{array}$ & Total \\
\hline 1 & Perkebunan & 4300.9 & 29897.5 & 24303.3 & 315170.4 & 64541.4 & 34211.7 & 12.3 & - & - & 294.0 & - & 172731.4 \\
\hline 2 & $\begin{array}{l}\text { Permukiman dan } \\
\text { tempat kegiatan }\end{array}$ & 3.5 & 5.1 & 1649.1 & $1 \quad 1436.3$ & 9.8 & 161.2 & 17304.1 & 6528.0 & 3475.8 & 14791.5 & 6306.0 & 51670.5 \\
\hline 3 & Mangrove & 32.6 & - & - & - & - & - & 19274.5 & 1405.0 & - & 92689.6 & 30199.4 & 143601.1 \\
\hline 4 & Hutan & 2515.2 & 28458.2 & 3888.0 & 6926.7 & 36254.9 & 12982.6 & 58.4 & - & - & 997.8 & - & 92081.8 \\
\hline 5 & Sawah & - & - & - & 42.0 & - & - & - & - & - & - & - & 42.0 \\
\hline 6 & Tegalan/Ladang & 6.2 & - & 886.2 & $2 \quad 1230.7$ & 49.1 & 30.2 & 1525.8 & 1022.0 & 91.7 & 2855.5 & 9504.1 & 17201.4 \\
\hline 7 & Semak belukar & 1063.8 & 13471.7 & 10250.7 & 715490.6 & 2578.9 & 608.7 & 14.5 & - & - & 371.8 & 22.3 & 43873.0 \\
\hline 8 & $\begin{array}{l}\text { Lahan } \\
\text { kosong/Gundul }\end{array}$ & - & - & $\cdot$ & - & 514.9 & 16.7 & - & - & - & - & - & 531.5 \\
\hline 9 & Danau /situ & - & - & - & - & 37.0 & 1.7 & 0.03 & - & - & - & 975.5 & 1014.3 \\
\hline 10 & Empang & - & - & 7.6 & 9.3 & 3.0 & 0.8 & 1.1 & - & - & - & - & 21.7 \\
\hline 11 & Tambak & - & - & 3.1 & 27.3 & - & - & - & - & - & - & - & 30.4 \\
\hline $\begin{array}{l}\text { Total } \\
\text { per ke }\end{array}$ & $\begin{array}{l}\text { luas } \\
\text { camatan }(\mathrm{Ha})\end{array}$ & 7922.2 & 71832.5 & 40987.9 & 9 40333.3 & 103989.0 & 48013.6 & 38190.7 & 8955.0 & 3567.6 & 112000.3 & 47007.2 & 522799.2 \\
\hline
\end{tabular}




\section{Area konsesi pada ekosistem gambut}

Berdasarkan ketentuan pada PP No. 71 Tahun 2014 jo. PP No. 57 Tahun 2016, terutama Pasal 9 ayat 3, Kementerian Lingkungan Hidup dan Kehutanan (KLHK) telah menetapkan peta fungsi ekosistem gambut nasional pada tanggal 27 Februari 2017. Di dalam peta tersebut, ekosistem gambut yang telah teridentifikasi dibagi dalam dua kategori, yaitu fungsi budidaya dan fungsi lindung, untuk selanjutnya digunakan sebagai acuan dalam penyusunan dan penetapan Rencana Perlindungan dan Pengelolaan Ekosistem Gambut nasional. Dalam rangka menggali informasi terkait kegiatan budidaya/konsesi baik untuk hutan tanaman maupun kelapa sawit, dilaksanakan overlay antara peta fungsi ekosistem gambut tahun 2017 dari KLHK dengan peta konsesi sawit dan hutan tanaman yang diperoleh dari Global Forest Watch-World Resources Institute (WRI) tahun 2017. Sebagaimana tersaji pada Gambar 6 dan Tabel 4, hasil overlay peta-peta tersebut memperlihatkan bahwa di Kabupaten Bengkalis, setidaknya terdapat 29280.4 Ha konsesi sawit dan 155 000.5 Ha konsesi hutan tanaman yang berada pada fungsi lindung ekosistem gambut (FLEG).

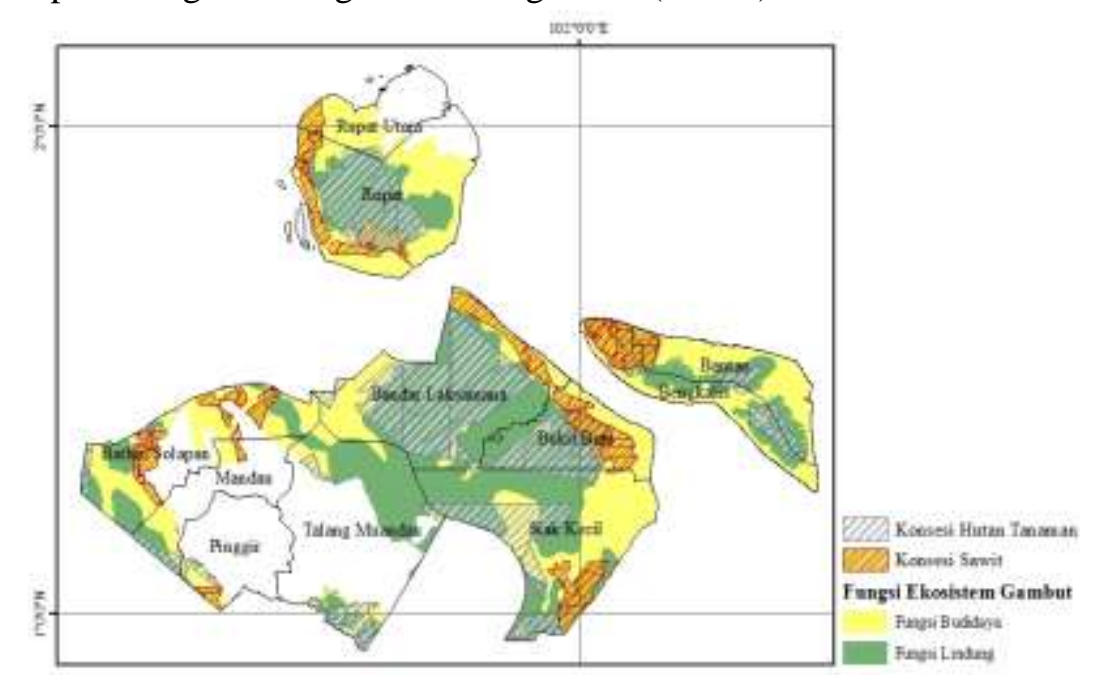

Gambar 6 Area konsesi pada ekosistem gambut di Kabupaten Bengkalis

Pada prinsipnya, pemerintah telah menyatakan bahwa perusahaan/pemegang izin konsesi yang berada pada FLEG masih diberi waktu untuk melanjutkan kegiatan usaha hingga sisa daur tanaman yang dilanjutkan dengan pemulihan. Namun demikian, tidak dapat dipungkiri bahwa pelarangan kegiatan budidaya pada FLEG akan memicu kontraksi ekonomi di Kabupaten Bengkalis. Setiawan dan Faroby (2017) melaporkan bahwa dengan adanya penurunan setidaknya 30\% luas lahan gambut budidaya untuk dialokasikan pada tujuan konservasi maka produksi CPO Indonesia juga akan berkurang menjadi 27.1 juta ton dari awalnya 28.5 juta ton. Pengurangan produksi tersebut bahkan dapat mencapai hanya 24.5-26.1 juta ton apabila 20-80\% luas lahan gambut dengan kedalaman lebih dari 3 meter harus diubah menjadi fungsi lindung. Angka tersebut juga diperkirakan dapat terus turun hingga produksi hanya mencapai 24.2- 25.1 juta ton apabila tinggi muka air gambut ditetapkan pada batas 0.4 meter dari permukaan. Sehingga secara keseluruhan, akan terjadi pengurangan produksi CPO antara 12-15\%. Sementara itu, dari jumlah tenaga kerja yang terlibat pada sektor perkebunan sawit secara nasional pada tahun 2015 yang mencapai 4.95 juta orang, diperkirakan antara 590 740 ribu orang akan kehilangan pekerjaannya, seiring dengan berkurangnya produksi sawit. Tingkat pengangguran yang lebih besar kemungkinan akan dialami oleh tenaga kerja pada kelompok perkebunan swasta dan berpotensi untuk memicu efek domino pada alur industri hulu ke hilir, hingga ke kalangan eksportir (Setiawan dan Faroby 2017).

Hal menarik lain dari hasil overlay peta tersebut adalah terlihatnya tumpang tindih/sengketa antara konsesi hutan tanaman yang dikelola oleh PT. L (nama perusahaan dalam alias/disamarkan) dan perkebunan sawit yang dikelola oleh PT. M di Kecamatan Bukit Batu. Hal yang sama juga ditemukan di wilayah Kecamatan Rupat, dimana terdapat tumpang tindih area antara hutan tanaman yang dikelola oleh PT. B dengan kebun 
sawit yang tidak diketahui pengelola dan status hukumnya (Tabel 4). Fenomena ini secara tidak langsung telah mengindikasikan adanya tantangan baru dalam implementasi pembatasan kegiatan pada area FLEG lainnya yaitu munculnya kawasan eks-konsesi pada area FLEG yang sering menjadi sasaran penguasaan lahan secara ilegal. Selain itu, seiring dengan menurunnya kegiatan operasional perusahaan pada area konsesi yang masuk dalam kategori FLEG maka pekerja/karyawan yang semula juga berperan dalam pengawasan area juga akan semakin berkurang. Bersamaan dengan berkurangnya SDM pengawasan tersebut disertai dengan masifnya infrastruktur, terutama jaringan jalan dan kanal (Gambar 7, Tabel 5 dan 6), yang telah dibangun oleh pemegang konsesi yang tidak lagi beroperasi secara penuh maka akan muncul berbagai area open access baru yang semakin memungkinkan terjadinya pembakaran lahan gambut secara sengaja, seperti yang telah dilaporkan oleh KLHK (2017). Apabila hal ini tidak diperhatikan secara serius, bukan tidak mungkin apabila pembakaran lahan gambut secara sengaja dan masif di Kabupaten Bengkalis akan terus terjadi. Penanganan lahan ekskonsesi seperti ini memerlukan kecermatan karena penggunaan api/pembakaran lahan dengan sengaja sering dijadikan sebagai alat dalam konflik penguasaan lahan gambut oleh pihak-pihak yang hendak mengambil keuntungan pribadi, sebagaimana telah dibuktikan oleh Chokkalingam et al. (2004) dan Medrilzam et al. (2017).

Tabel 4 Tumpang susun konsesi pada lahan gambut di Kabupaten Bengkalis

\begin{tabular}{|c|c|c|c|c|c|}
\hline \multirow[b]{2}{*}{ No. } & \multirow[b]{2}{*}{ Kecamatan } & \multirow[b]{2}{*}{$\begin{array}{l}\text { Pemegang } \\
\text { Konsesi }\end{array}$} & \multirow[b]{2}{*}{$\begin{array}{c}\text { Tipe } \\
\text { Konsesi }\end{array}$} & \multicolumn{2}{|c|}{ Luas area } \\
\hline & & & & $\begin{array}{l}\text { Fungsi } \\
\text { Budidaya } \\
\text { (Ha) }\end{array}$ & $\begin{array}{l}\text { Fungsi } \\
\text { Lindung } \\
\text { (Ha) }\end{array}$ \\
\hline \multirow[t]{2}{*}{1} & \multirow[t]{2}{*}{ Rupat Utara } & PT. A & Sawit & 2562.1 & 161.4 \\
\hline & & PT. B & HT & 505.1 & 619.5 \\
\hline \multirow[t]{5}{*}{2} & \multirow{5}{*}{ Rupat } & PT. A & Sawit & 1430.9 & 1216.6 \\
\hline & & PT. C & Sawit & 3498.2 & 463.3 \\
\hline & & PT. D & Sawit & 1592.8 & 366.5 \\
\hline & & Tidak ada nama & Sawit & 381.4 & 4627.6 \\
\hline & & PT. B & $\mathrm{HT}$ & 2368.7 & 35004.1 \\
\hline \multirow[t]{2}{*}{3} & \multirow[t]{2}{*}{ Bantan } & PT. E & Sawit & 1195.7 & 2499.0 \\
\hline & & PT. F & HT & 220.7 & 5369.7 \\
\hline \multirow[t]{2}{*}{4} & \multirow[t]{2}{*}{ Bengkalis } & PT. E & Sawit & 4385.2 & 5913.4 \\
\hline & & PT. F & HT & 969.2 & 4916.8 \\
\hline \multirow[t]{6}{*}{5} & \multirow[t]{6}{*}{ Bandar Laksamana } & PT. G & Sawit & 5296.1 & 85.6 \\
\hline & & PT. H & Sawit & 726.9 & 77.3 \\
\hline & & PT. I & HT & 162.5 & - \\
\hline & & PT. J & HT & 1875.1 & 30803.5 \\
\hline & & PT. K & HT & 2162.4 & 8164.5 \\
\hline & & PT. L & HT & 261.8 & 22917.4 \\
\hline \multirow[t]{3}{*}{6} & \multirow[t]{3}{*}{ Bukit Batu } & PT. M & Sawit & 5621.6 & 5293.0 \\
\hline & & PT. N & Sawit & 1634.7 & 99.5 \\
\hline & & PT. L & HT & 1234.9 & 18630.6 \\
\hline \multirow[t]{8}{*}{7} & \multirow[t]{8}{*}{ Siak Kecil } & PT. M & Sawit & 257.3 & - \\
\hline & & PT. O & Sawit & 3116.5 & 4192.1 \\
\hline & & PT. P & Sawit & 131.2 & 2260.8 \\
\hline & & PT. Q & HT & 3338.8 & 4090.5 \\
\hline & & PT. S & HT & - & 19.1 \\
\hline & & PT. K & HT & 7887.8 & 11782.1 \\
\hline & & PT. L & HT & 74.7 & 2982.5 \\
\hline & & PT. R & HT & 116.9 & 1245.6 \\
\hline \multirow[t]{3}{*}{8} & \multirow[t]{3}{*}{ Bathin Solapan } & PT. T & Sawit & 1374.5 & - \\
\hline & & PT. U & Sawit & 1006.2 & 394.6 \\
\hline & & PT. V & Sawit & 827.7 & 868.2 \\
\hline
\end{tabular}




\begin{tabular}{|c|c|c|c|c|c|}
\hline \multirow{6}{*}{ No. } & \multirow{6}{*}{ Kecamatan } & \multirow[b]{2}{*}{$\begin{array}{l}\text { Pemegang } \\
\text { Konsesi }\end{array}$} & \multirow[b]{2}{*}{$\begin{array}{c}\text { Tipe } \\
\text { Konsesi }\end{array}$} & \multicolumn{2}{|c|}{ Luas area } \\
\hline & & & & $\begin{array}{l}\text { Fungsi } \\
\text { Budidaya } \\
\text { (Ha) }\end{array}$ & $\begin{array}{l}\text { Fungsi } \\
\text { Lindung } \\
\text { (Ha) }\end{array}$ \\
\hline & & PT. W & Sawit & 243.2 & 590.7 \\
\hline & & PT. I & HT & 43.0 & - \\
\hline & & PT. X & HT & 191.4 & 1092.0 \\
\hline & & PT. Y* & HT & - & 169.4 \\
\hline \multirow[t]{2}{*}{9} & Mandau & PT. Z & Sawit & 75.6 & - \\
\hline & & PT. Y* & HT & 702.3 & 2385.5 \\
\hline \multirow[t]{3}{*}{10} & Pinggir & PT. AA & Sawit & 1426.6 & 170.6 \\
\hline & & KOP. AB & $\mathrm{HT}$ & 31.7 & - \\
\hline & & PT. Y* & HT & 257.1 & 116.9 \\
\hline \multirow[t]{3}{*}{11} & Talang Muandau & PT. I & HT & 2944.8 & 4271.8 \\
\hline & & PT. K & HT & 671.4 & 218.9 \\
\hline & & PT. L & $\mathrm{HT}$ & - & 1.6 \\
\hline Total & as area $(\mathrm{Ha})$ & & & 62804.5 & 184082.3 \\
\hline
\end{tabular}

Keterangan: nama perusahaan dalam alias/disamarkan, * Izin IUPHHK-HT telah dicabut (KLHK 2017)

Gambaran padatnya jaringan jalan dan kanal yang telah dibangun pada ekosistem gambut di Kabupaten Bengkalis secara rinci tersaji pada Tabel 5 dan 6 yang dihasilkan dari tumpang susun antara peta fungsi ekosistem gambut nasional dari KLHK dengan peta jaringan jalan dan drainase buatan/kanal dari BIG. Berdasarkan kedua tabel tersebut diketahui bahwa hampir seluruh KHG di Kabupaten Bengkalis telah mengalami pembangunan jaringan jalan dan kanal yang padat, terutama pada area FLEG, seperti pada KHG Pulau Rupat (Kec. Rupat dan Rupat Utara), KHG Pulau Bengkalis (Kec. Bantan dan Bengkalis), KHG Sungai Rokan-Sungai Siak Kecil (Kec. Bathin Solapan, Bandar Laksamana, Mandau, dan Bukit Batu), KHG Sungai Rokan Kiri-Sungai Mandau (Kec. Mandau dan Pinggir), serta KHG Sungai Siak Kecil-Sungai Siak (Kec. Talang Muandau). Melihat padatnya jaringan infrastruktur jalan dan kanal yang terbangun tersebut, maka timbul pertanyaan mengenai kesiapan pemerintah, terutama Organisasi Perangkat Daerah (OPD) setempat, dalam menjamin ketersediaan anggaran serta sumberdaya manusia (SDM) yang dibutuhkan baik dalam rangka pengawasan maupun pemeliharaannya. Hal ini penting mengingat seiring dengan implementasi PP No. 71 Tahun 2014 jo. PP No. 57 Tahun 2016 maka kegiatan operasional perusahaan pada area konsesi yang masuk dalam kategori FLEG akan berkurang secara drastis. Tanpa dukungan pendanaan serta ketersediaan SDM yang dibutuhkan dalam pengawasan dan pemeliharaan yang semula berada di bawah tanggungjawab perusahaan, maka infratruktur (e.g. jaringan jalan dan kanal) yang terbangun cenderung akan terbengkalai dan rusak. Dalam jangka panjang, terbengkalainya infrastruktur yang telah terbangun tersebut dapat meningkatkan kerawanan terhadap kerusakan ekosistem gambut. Sebagaimana dilaporkan oleh Latifah dan Pamungkas (2013), serta Irma et al. (2018) bahwa tanpa pengawasan yang cukup, ketersediaan jaringan jalan cenderung meningkatkan kerentanan terjadinya kebakaran hutan dan lahan di kawasan tersebut. Disamping itu, Lisnawati et al. (2015) menyatakan bahwa jaringan kanal sangat berperan dalam pengendalian tinggi muka air gambut. Oleh karena itu, terbengkalainya jaringan kanal yang telah terbangun secara masif dapat mempersulit pengaturan tinggi muka air yang penting dalam menjaga kelestarian lahan gambut di kabupaten ini. Mempertimbangkan berbagai hasil studi tersebut, dapat dipahami bahwa implementasi kebijakan perlindungan ekosistem gambut pada prinsipnya memerlukan kecermatan dan kesiapan pemerintah, baik dari segi anggaran maupun SDM, dalam rangka menghindari timbulnya berbagai permasalahan di masa mendatang. 


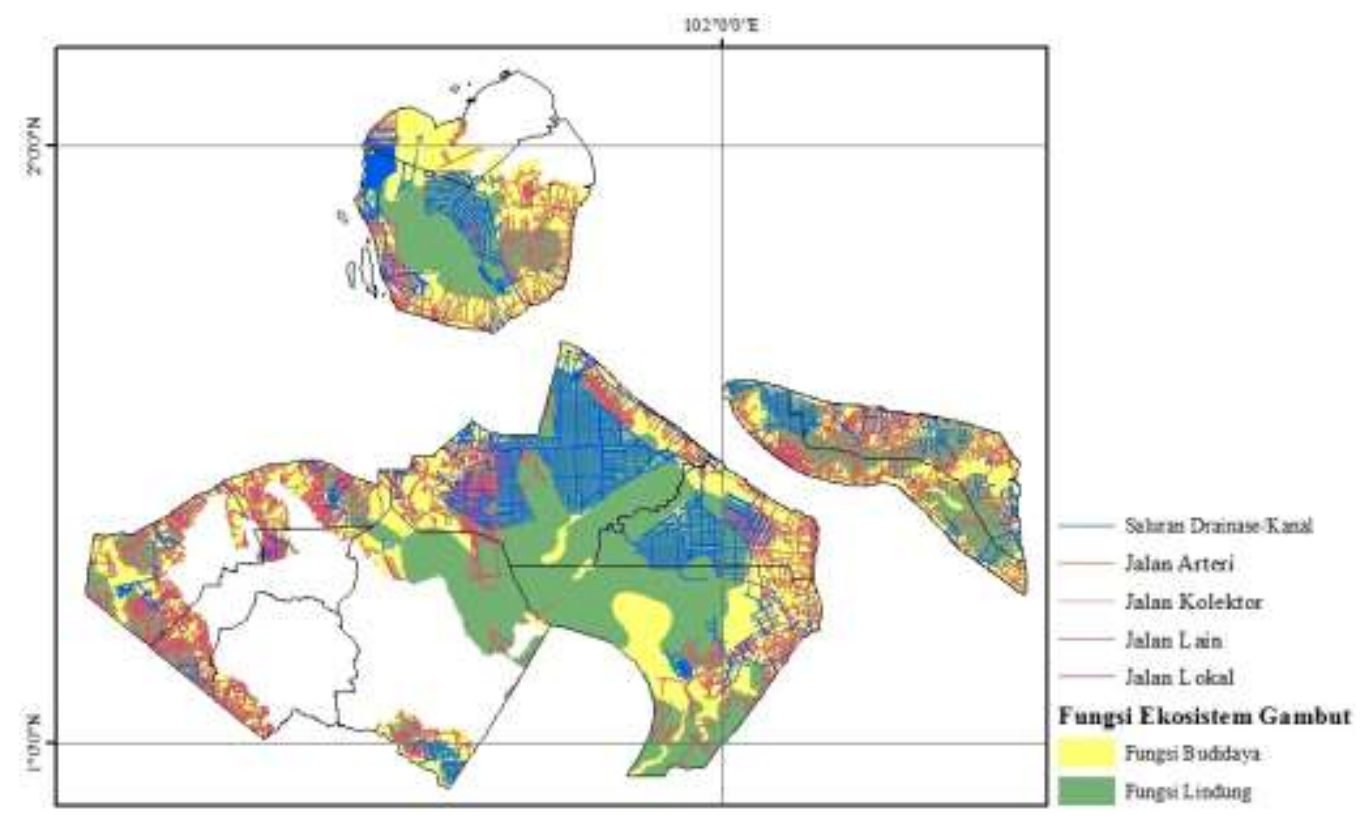

Gambar 7 Jaringan jalan dan kanal pada ekosistem gambut di Kabupaten Bengkalis

Tabel 5 Panjang jaringan jalan dan kanal pada ekosistem gambut di Kabupaten Bengkalis

\begin{tabular}{|c|c|c|c|c|c|c|}
\hline \multirow{3}{*}{ No } & \multirow{3}{*}{ Kecamatan } & \multirow{3}{*}{$\begin{array}{l}\text { Kesatuan Hidrologis Gambut } \\
\text { (KHG) }\end{array}$} & \multicolumn{4}{|c|}{$\begin{array}{l}\text { Panjang pada tiap fungsi ekosistem gambut } \\
\qquad(\mathrm{Km})\end{array}$} \\
\hline & & & \multicolumn{2}{|c|}{ Fungsi Lindung } & \multicolumn{2}{|c|}{ Fungsi Budidaya } \\
\hline & & & Jalan & Kanal & Jalan & Kanal \\
\hline 1 & Rupat & KHG Pulau Rupat & 609.7 & 350.6 & 742.2 & 266.0 \\
\hline 2 & Rupat Utara & KHG Pulau Rupat & 17.7 & 17.3 & 132.2 & 87.1 \\
\hline 3 & Bantan & KHG Pulau Bengkalis & 219.4 & 97.8 & 599.3 & 183.8 \\
\hline 4 & Bengkalis & KHG Pulau Bengkalis & 176.4 & 123.8 & 413.5 & 57.5 \\
\hline \multirow[t]{2}{*}{5} & Bathin Solapan & $\begin{array}{l}\text { KHG Sungai Rokan-Sungai Siak } \\
\text { Kecil }\end{array}$ & 255.8 & 30.7 & 748.0 & 56.4 \\
\hline & & $\begin{array}{l}\text { KHG Sungai Rokan Kiri-Sungai } \\
\text { Mandau }\end{array}$ & 161.1 & 7.2 & 152.0 & 45.4 \\
\hline \multirow[t]{2}{*}{6} & \multirow[t]{2}{*}{ Mandau } & $\begin{array}{l}\text { KHG Sungai Rokan Kiri-Sungai } \\
\text { Mandau }\end{array}$ & 121.3 & 12.5 & 162.8 & 0.8 \\
\hline & & $\begin{array}{l}\text { KHG Sungai Rokan - Sungai Siak } \\
\text { Kecil }\end{array}$ & 2.4 & - & 222.6 & 26.5 \\
\hline 7 & Pinggir & $\begin{array}{l}\text { KHG Sungai Rokan Kiri-Sungai } \\
\text { Mandau }\end{array}$ & 22.6 & - & 172.9 & \\
\hline \multirow{3}{*}{8} & \multirow{3}{*}{ Talang Muandau } & $\begin{array}{l}\text { KHG Sungai Bunut - Sungai } \\
\text { Umban }\end{array}$ & 74.5 & 65.8 & 74.2 & 26.7 \\
\hline & & $\begin{array}{l}\text { KHG Sungai Siak Kecil-Sungai } \\
\text { Siak }\end{array}$ & 1.7 & - & 2.9 & \\
\hline & & $\begin{array}{l}\text { KHG Sungai Rokan - Sungai Siak } \\
\text { Kecil }\end{array}$ & 93.8 & 1.5 & 36.8 & 7.0 \\
\hline 9 & $\begin{array}{l}\text { Bandar } \\
\text { Laksamana }\end{array}$ & $\begin{array}{l}\text { KHG Sungai Rokan - Sungai Siak } \\
\text { Kecil }\end{array}$ & 690.9 & 1045.8 & 563.4 & 248.1 \\
\hline 10 & Bukit Batu & $\begin{array}{l}\text { KHG Sungai Rokan-Sungai Siak } \\
\text { Kecil }\end{array}$ & 92.7 & 399.7 & 324.0 & 81.2 \\
\hline
\end{tabular}




\begin{tabular}{|c|c|c|c|c|c|c|}
\hline \multirow{3}{*}{ No } & \multirow{3}{*}{ Kecamatan } & \multirow{3}{*}{$\begin{array}{l}\text { Kesatuan Hidrologis Gambut } \\
\text { (KHG) }\end{array}$} & \multicolumn{4}{|c|}{$\begin{array}{l}\text { Panjang pada tiap fungsi ekosistem gambut } \\
\qquad(\mathrm{Km})\end{array}$} \\
\hline & & & \multicolumn{2}{|c|}{ Fungsi Lindung } & \multicolumn{2}{|c|}{ Fungsi Budidaya } \\
\hline & & & Jalan & Kanal & Jalan & Kanal \\
\hline \multirow{5}{*}{11} & & KHG Sungai Rokan-Sungai Siak & & & & \\
\hline & Siak Kecil & Kecil & 60.6 & 71.6 & 236.3 & 75.2 \\
\hline & & $\overline{\text { KHG Sungai Siak Kecil-Sungai }}$ & & & & \\
\hline & & Siak & 109.4 & 3.1 & 219.5 & 40.6 \\
\hline & & jang Total $(\mathrm{km})$ & 2709.9 & 2227.4 & 4802.7 & 1202.3 \\
\hline
\end{tabular}

Tabel 6 Kepadatan jaringan jalan dan kanal pada ekosistem gambut di Kabupaten Bengkalis

\begin{tabular}{|c|c|c|c|c|c|c|}
\hline \multirow{3}{*}{ No. } & \multirow{3}{*}{ Kecamatan } & \multirow{3}{*}{$\begin{array}{l}\text { Kesatuan Hidrologis Gambut } \\
\text { (KHG) }\end{array}$} & \multicolumn{4}{|c|}{$\begin{array}{l}\text { Kepadatan pada tiap fungsi ekosistem gambut } \\
\qquad\left(\mathrm{Km} / \mathrm{Km}^{2}\right)\end{array}$} \\
\hline & & & \multicolumn{2}{|c|}{ Fungsi Lindung } & \multicolumn{2}{|c|}{ Fungsi Budidaya } \\
\hline & & & Jalan & Kanal & Jalan & Kanal \\
\hline 1 & Rupat & KHG Pulau Rupat & 1.24 & 0.71 & 1.49 & 0.53 \\
\hline 2 & Rupat Utara & KHG Pulau Rupat & 2.24 & 2.19 & 0.72 & 1.45 \\
\hline 3 & Bantan & KHG Pulau Bengkalis & 1.13 & 0.51 & 2.16 & 0.66 \\
\hline 4 & Bengkalis & KHG Pulau Bengkalis & 0.84 & 0.59 & 1.84 & 0.26 \\
\hline \multirow[t]{2}{*}{5} & \multirow[t]{2}{*}{ Bathin Solapan } & $\begin{array}{l}\text { KHG Sungai Rokan-Sungai } \\
\text { Siak Kecil }\end{array}$ & 2.15 & 0.26 & 2.32 & 0.17 \\
\hline & & $\begin{array}{l}\text { KHG Sungai Rokan Kiri- } \\
\text { Sungai Mandau }\end{array}$ & 1.94 & 0.09 & 1.58 & 0.47 \\
\hline \multirow[t]{2}{*}{6} & \multirow[t]{2}{*}{ Mandau } & $\begin{array}{l}\text { KHG Sungai Rokan Kiri- } \\
\text { Sungai Mandau }\end{array}$ & 2.55 & 0.26 & 2.84 & 0.01 \\
\hline & & $\begin{array}{l}\text { KHG Sungai Rokan - Sungai } \\
\text { Siak Kecil }\end{array}$ & 0.86 & - & 5.33 & 0.63 \\
\hline 7 & Pinggir & $\begin{array}{l}\text { KHG Sungai Rokan Kiri- } \\
\text { Sungai Mandau }\end{array}$ & 3.09 & - & 2.93 & - \\
\hline \multirow{3}{*}{8} & \multirow{3}{*}{ Talang Muandau } & $\begin{array}{l}\text { KHG Sungai Bunut - Sungai } \\
\text { Umban }\end{array}$ & 1.34 & 1.18 & 1.11 & 0.40 \\
\hline & & $\begin{array}{l}\text { KHG Sungai Siak Kecil-Sungai } \\
\text { Siak }\end{array}$ & 1.00 & - & 4.39 & - \\
\hline & & $\begin{array}{l}\text { KHG Sungai Rokan - Sungai } \\
\text { Siak Kecil }\end{array}$ & 0.28 & 0.00 & 0.47 & 0.09 \\
\hline 9 & Bandar Laksamani & $\begin{array}{l}\text { KHG Sungai Rokan - Sungai } \\
\text { Siak Kecil }\end{array}$ & 0.79 & 1.19 & 1.50 & 0.66 \\
\hline 10 & Bukit Batu & $\begin{array}{l}\text { KHG Sungai Rokan-Sungai } \\
\text { Siak Kecil }\end{array}$ & 0.29 & 1.26 & 1.50 & 0.38 \\
\hline \multirow[t]{2}{*}{11} & \multirow[t]{2}{*}{ Siak Kecil } & $\begin{array}{l}\text { KHG Sungai Rokan-Sungai } \\
\text { Siak Kecil }\end{array}$ & 0.12 & 0.15 & 0.65 & 0.21 \\
\hline & & $\begin{array}{l}\text { KHG Sungai Siak Kecil-Sungai } \\
\text { Siak }\end{array}$ & 0.57 & 0.02 & 1.35 & 0.25 \\
\hline
\end{tabular}




\section{SIMPULAN}

Wilayah administrasi kabupaten Bengkalis didominasi oleh lahan gambut yang setidaknya mencapai 522799.2 ha atau $67.25 \%$ dari total wilayah administrasinya. Lahan gambut yang ada di kabupaten ini memiliki karakteristik kedalaman dan tingkat dekomposisi yang sangat bervariatif. Selain itu, pada wilayah administrasi Kabupaten Bengkalis yang terbagi atas 11 kecamatan ini, terdapat enam kesatuan hidrologis gambut, yang mayoritas telah ditetapkan sebagai fungsi lindung ekosistem gambut. Namun demikian, tipe tutupan dan penggunaannya didominasi oleh perkebunan dan hutan rimba, yang apabila ditinjau lebih lanjut, telah terdapat banyak berdiri area konsesi sawit dan hutan tanaman, baik yang berizin (legal) maupun tidak berijin (illegal). Mempertimbangkan hasil penelitian tersebut, apabila dihadapkan dengan implementasi kebijakan perlindungan ekosistem gambut sebagaimana diamanatkan dalam PP No. 71 Tahun 2014 jo. PP No. 57 Tahun 2016, telah teridentifikasi beragam tantangan yang timbul. Pertama, penerapan/pengukuran kriteria gambut rusak berdasarkan tinggi muka air gambut $0.4 \mathrm{~m}$. Kedua, potensi friksi antara kebutuhan insentif perlindungan dan tekanan atas konversi lahan gambut terutama pada wilayah-wilayah yang baru dimekarkan. Ketiga, adanya potensi kontraksi ekonomi sebagai akibat dari adanya pengurangan kegiatan produksi dan efisiensi karyawan. Keempat, munculnya berbagai area open access baru pada lahan gambut dimana perusahaan-perusahaan tidak lagi beroperasi secara penuh, maupun pada lahan eks-konsesi, yang sering menjadi sasaran penguasaan lahan secara illegal dan pembakaran lahan dengan sengaja. Sebagai implikasi dari tantangan tersebut, maka pemerintah selaku regulator semestinya dapat membuka pintu bagi ruang perbaikan kebijakan. Pertama, merevisi kriteria tinggi muka air untuk menilai gambut rusak dengan nilai ambang yang bersifat dinamis pada suatu kisaran (misal $0.4-0.8 \mathrm{~m}$ ). Kedua, segera merumuskan dan memperjelas program penggantian lahan usaha untuk menggantikan areal gambut yang direstorasi agar setidaknya dapat mengurangi ketegangan para tenaga kerja yang berpotensi kehilangan pekerjaannya. Ketiga, memberi perhatian yang berimbang antara tiga aspek penting dalam sustainable development, yang mencakup keberlanjutan lingkungan, sosial, dan ekonomi dalam implementasi kebijakan perlindungan ekosistem gambut.

\section{UCAPAN TERIMA KASIH}

Penulis menyampaikan terima kasih sebesar-besarnya kepada Lembaga Pengelola Dana Pendidikan (LPDP) yang telah memberikan dukungan finansial hingga penelitian ini dapat terlaksana dengan baik. Ucapan terima kasih juga penulis sampaikan kepada Badan Pusat Statistik (BPS), Badan Informasi Geospasial (BIG), Kementerian Lingkungan Hidup dan Kehutanan RI, Wetlands International Indonesia (WII), Kementerian Pertanian RI, dan World Resources Institute (WRI) yang telah menyediakan data yang diperlukan dalam penelitian. Terima kasih juga kami sampaikan kepada para reviewer atas segala saran dan masukan pada naskah publikasi penelitian ini.

\section{DAFTAR PUSTAKA}

[BPS] Badan Pusat Statistik Kabupaten Bengkalis. 2017. Kabupaten Bengkalis Dalam Angka 2017. Bengkalis (245): BPS Kab. Bengkalis.

[IOPRI] Indonesia Oil Palm Research Institute, 2017. Permasalahan Implementasi PP 57 tahun 2016 di Perkebunan Kelapa Sawit di Lahan Gambut [Internet]. Materi Pertemuan Teknis Kelapa Sawit, Solo 18-20 Juli 2017; [diunduh 10 Oktober 2017]. Tersedia pada: http://www.iopri.org/wpcontent/uploads/2017/07/IX-01.-MATERI-PTKS-2017SOLO_WIN.pdf.

[KLHK] Kementerian Lingkungan Hidup dan Kehutanan. 2017. Pembakaran lahan di Riau masif dan disengaja. Siaran Pers No. SP. 150/HUMAS/PP.HMS.3/07/2017.

Agus F, Anda M, Jamil A, Masganti. 2016. Lahan Gambut Indonesia: Pembentukan, Karakteristik, dan Potensi. Jakarta (246): IAARD Press. 
Andriesse JP. 1988. Nature and Management of Tropical Peat Soils. Roma (165): FAO Land and Water Development Division.

Chokkalingam U, Suyanto S, Permana RP, Kurniawan I, Mannes J, Darmawan A, Khususiyah N, Susanto RS. 2004. Pengelolaan Api, Perubahan Sumberdaya Alam dan Pengaruhnya terhadap Kehidupan Masyarakat di Areal Rawa/Gambut - Sumatera Bagian Selatan. CIFOR Research Paper. 979-3361-492.

Djaelani MS. 2011. Analisis kebijakan penataan ruang dan dukungan partisipasi masyarakat terhadap kelestarian lingkungan. Jurnal Pengelolaan Sumberdaya Alam dan Lingkungan. 1(2):135-145.

Irma W, Gunawan T, Suratman. 2018. Pengaruh konversi lahan gambut terhadap ketahanan lingkungan di DAS Kampar Provinsi Riau Sumatera. Jurnal Ketahanan Nasional. 24(2):170-191.

Latifah RN, Pamungkas A. 2013. Identifikasi faktor-faktor kerentanan terhadap bencana kebakaran hutan dan lahan di Kecamatan Liang Anggang Kota Banjarbaru. Jurnal Teknik Institut Teknologi Sepuluh November. 2(2):1-4.

Lisnawati Y, Suprijo H, Poedjirahajoe E, Musyafa. 2015. Dampak pembangunan hutan tanaman industri Acacia crassicarpa di lahan gambut terhadap tingkat kematangan dan laju penurunan permukaan tanah. Jurnal Manusia dan Lingkungan. 22(2):179-186.

Mayring P. 2014. Qualitative Content Analysis: Theoretical Foundation, Basic Procedures and Software Solution. Klagenfurt (143): Leibniz-Institut fur Sozialwissenschaften.

Medrilzam, Rahayu NH, Widiaryanto P, Rosylin L, Firdaus R, Suprapto U, Sumantri, Purnomo H, Wulan YC, Tarigan MLP, Nugraha M. 2017. Grand Design Pencegahan Kebakaran Hutan, Kebun, dan Lahan 2017-2019 Republik Indonesia. Jakarta (84): Direktorat Kehutanan dan Sumberdaya Air BAPPENAS.

Miettinen J, Shi C, Liew SC. 2016. Land cover distribution in the peatlands of Peninsular Malaysia, Sumatera, and Borneo in 2015 with changes since 1990. Global Ecology and Conservation. 6:67-78.

Pranoto DY, Hardiyansyah G, Fahrizah, Diba F, Hendarto, Arief FB, Marcellus M, Yani A, Suryadi A, Indraningsih W, Achsani H, Darea. 2017. Penilaian rencana perlindungan dan pengelolaan ekosistem gambut (PPEG) Provinsi Kalimantan Barat antara sistem pendukung-kebijakan atau advokasi. Prosiding Seminar Nasional Penerapan Ilmu Pengetahuan dan Teknologi, Pontianak 23-24 Mei 2017. Pontianak: Universitas Tanjungpura.

Purbawiyatna A, Kartodiharjo H, Alikodra HS, Prasetyo LB. 2012. Analisis kebijakan pengelolaan hutan rakyat untuk mendorong fungsi lindung. Jurnal Pengelolaan Sumberdaya Alam dan Lingkungan. 2(1):1-10.

Ritung S, Wahyunto, Nugroho K, Sukarman, Hikmatullah, Suparto, Tafakresnanto C. 2011. Peta Lahan Gambut Indonesia Skala 1:250.000 (Indonesian peatland map at the scale 1:250.000). Bogor: Balai Besar Sumberdaya Lahan Pertanian-Kementerian Pertanian.

Setiawan BI, Faroby F. 2017. Peat policy and its implications on value chains of Indonesian palm oil. Eria Discussion Paper. ERIA-DP-2017-02.

Soil Survey Staff. 2014. Keys to Soil Taxonomy $12^{\text {th }}$ Edition. Washington DC (362): United States Department of Agriculture (USDA)

Subiksa IGM, Wahyunto. 2013. Genesis Lahan Gambut Indonesia. Prosiding Seminar Nasional Pengelolaan Lahan Gambut Berkelanjutan, Bogor 4 Mei 2012. Bogor (466): Badan Penelitian dan Pengembangan, Kementerian Pertanian.

Suwarno Y, Purwono N, Suriadi AB, Nahib I. 2016. Kajian kesatuan hidrologis gambut wilayah Kalimantan Tengah. Prosiding Seminar Nasional Peran Geospasial dalam Membingkai NKRI, Bogor 5 Oktober 2016. Bogor (329): Badan Informasi Geospasial. 
Syahza A. 2011. Percepatan ekonomi pedesaan melalui pembangunan perkebunan kelapa sawit. Jurnal Ekonomi Pembangunan. 12(2):297-310.

Wahyunto, Nugroho K, Ritung S, Sulaeman Y. 2014. Peta lahan gambut Indonesia: metode pembuatan, tingkat keyakinan, dan penggunaan. Working Paper of Indonesian Center for Agricultural Land Resources Research and Development.

Wahyunto, Ritung S, Suparto, Subagjo H. 2004. Map of Peatland Distribution and its C content in Kalimantan. Bogor (10): Wetlands International-Indonesia Programme and Wildlife Habitat Canada.

Wahyunto, Ritung S, Suparto, Subagjo H. 2005. Sebaran Gambut dan Kandungan Karbon di Sumatera dan Kalimantan. Bogor (254): Wetlands International-Indonesia Programme.

Wardani DM. 2016. Satu harapan: pakar gambut minta PP 57/2016 direvisi [Internet]. [diunduh 10 Oktober 2017]. Tersedia pada: http://www.satuharapan.com/read-detail/read/pakar-gambut-minta-pp-572016direvisi.

Winarna. 2015. Pengaruh kedalaman muka air tanah dan dosis terak baja terhadap hidrofobisitas tanah gambut, emisi karbon, dan produksi kelapa sawit (disertasi). Bogor (100): Institut Pertanian Bogor.

Worall L, Bond D. 1997. Geographical information system, spatial analysis, and public policy: the British experience. International Statistical Review. 65(3):365-379.

Zook M, Wollersheim D, Erbas B, Jacobsen KH. 2018. Integrating spatial analysis into policy formulation: a case study examining traffic exposure and asthma. World Medical and Health Policy. 10(1):99-110. 